\title{
Evaluasi Kinerja Keuangan Sebelum dan Sesudah Akuisisi Menggunakan Profitabilitas
}

\author{
Muhammad Hamdan Sayadi ${ }^{1)}$ \\ ${ }^{1)}$ Program Studi Akuntansi, Universitas Indo Global Mandiri \\ Jl. Jendral Sudirman KM.4 Palembang \\ Email : hamdansayadi@uigm.ac.id ${ }^{1)}$
}

\begin{abstract}
The objective of this research aims to evaluate of financial performance the acquirer company before and after acquisition and company condition after acquisition that being evaluated with Economic Value Added (EVA) method. This study was classified as a descriptive study with case study approach. Data collection was collected by documentation method in the form of annual financial report of PT Elang Mahkota Teknologi Tbk. in the period of three years before acquisition and four years after acquisition (2009-2015). Ratio analysis were used as evaluation tools on this research. Ratio analysis used the profitability ratio. Ratio analysis results showed that profitability ratios have increased after the acquisition. Profit margin ratio before acquisition have increased from 0,06 in 2009 to 0,15 in 2010. Profit margin ratio PT Elang Mahkota Teknologi Tbk also have increased after acquisition from 0,15 in 2010 to 0,29 in 2015. Before acquisition, ROA PT Elang Mahkota Teknologi Tbk have increased from 0,04 in 2009 to 0,12 in 2010. And then, ROA have decreased to 0,11 after acquisition. ROE PT Elang Mahkota Teknologi Tbk have increased before acquisition from 0,06 in 2009 to 0,16 in 2010. But ROE have decreased to 0,12 after acquisition. Based on the research results, financial performance of PT Elang Mahkota Teknologi Tbk. after acquisition is better than before the acquisition period.
\end{abstract}

Keywords : Financial performance, Economic Value Added, Financial ratio

\begin{abstract}
ABSTRAK
Penelitian ini bertujuan untuk mengevaluasi kinerja keuangan perusahaan pengakuisisi sebelum dan setelah akuisisi dan kondisi perusahaan pengakuisisi setelah akuisisi yang dievaluasi dengan menggunakan metode nilai tambah. Studi ini tergolong sebagai penelitian deskriptif dengan pendekatan studi kasus. Pengumpulan data dilakukan dengan metode dokumentasi berupa laporan keuangan tahunan PT Elang Mahkota Teknologi Tbk. periode tiga tahun sebelum dan empat tahun setelah akuisisi (2009-2015). Alat evaluasi yang digunakan ialah analisis rasi. Analisis rasio yang digunakan dalam penelitian ini ialah rasio profitabilitas. Pada rasio profit margin periode sebelum akuisisi mengalami peningkatan dari 0,06 pada tahun 2009 menjadi 0,15 pada tahun 2010. Profit margin PT Elang Mahkota Teknologi Tbk terus mengalami peningkatan pada periode setelah akuisisi hingga mencapai 0,29 pada tahun 2015. Pada periode sebelum akuisisi nilai ROA mengalami peningkatan dari 0,04 pada tahun 2009 menjadi 0,12 pada tahun 2010. ROA meningkat karena meningkatnya laba bersih sehingga kemampuan pengembalian aktivanya juga menjadi semakin kuat. Akan tetapi pada periode setelah akuisisi ROA perusahaan mengalami penurunan menjadi sebesar 0,11 pada tahun 2015. Penurunan tersebut menunjukkan bahwa efisiensi dan efektivitas pengelolaan aset tidak lebih baik daripada periode sebelum akuisisi. Pada periode sebelum akuisisi nilai ROE mengalami peningkatan dari 0,06 pada tahun 2009 menjadi 0,16 pada tahun 2010. Akan tetapi pada periode setelah akuisisi ROE perusahaan mengalami penurunan menjadi sebesar 0,12 pada tahun 2015. Peningkatan dan penurunan ROE dikarenakan mengikuti kenaikan dan penurunan laba bersih perusahaan. Berdasarkan hasil penelitian, kinerja keuangan PT Elang Mahkota Teknologi Tbk setelah akuisisi lebih baik dibandingkan periode sebelum akuisisi.
\end{abstract}

Kata kunci: Kinerja keuangan, Economic Value Added, rasio keuangan. 


\section{Pendahuluan}

\section{A. Latar Belakang}

Indonesia memasuki Masyarakat Ekonomi Asean (MEA) pada tahun 2016. Masyarakat Ekonomi Asean menyebabkan persaingan antarperusahaan di Asia Tenggara menjadi semakin ketat. Perubahan kondisi ini menuntut setiap perusahaan untuk mengevaluasi kinerja mereka dan merancang strategi yang akan mereka terapkan. Perusahaan dapat berkembang dan bersaing serta memperluas pangsa pasarnya dengan melakukan kombinasi bisnis. Kombinasi bisnis adalah suatu transaksi atau peristiwa lain dimana pihak pengakuisisi memperoleh pengendalian atas satu atau lebih bisnis. Salah satu jenis kombinasi bisnis yang dapat dilakukan oleh perusahaan ialah akuisisi. Akuisisi adalah suatu penggabungan usaha dimana salah satu perusahaan, yaitu pengakuisisi (acquirer) memperoleh kendali atas aset neto dan operasi perusahaan yang diakuisisi (acquiree), dengan memberikan aset tertentu, mengakui suatu kewajiban, atau mengeluarkan saham (PSAK 22, 2010).

Kinerja perusahaan merupakan hasil dari keputusankeputusan yang diambil oleh manajer dalam menjalankan suatu perusahaan. Kinerja perusahaan dapat dikategorikan menjadi dua yaitu kinerja pasar dan kinerja keuangan. Kinerja pasar berhubungan dengan nilai perusahaan di pasar modal. Kinerja pasar suatu perusahaan mencerminkan seberapa baik prospek suatu perusahaan di mata investor. Berbeda dengan kinerja keuangan bersifat historis, yang artinya kinerja keuangan dihitung berdasarkan informasi-informasi sebelumnya. Kinerja keuangan perusahaan dilihat dari perbandingan rasio-rasio keuangan dengan menggunakan data akuntansi.

Meningkatnya aktivitas merger dan akuisisi di dunia industri perbankan didorong oleh adanya perubahan kondisi ekonomi. Terdapat lima perubahan pokok dalam perekonomian yang mendorong maraknya aktivitas merger dan akuisisi yaitu kemajuan teknologi, meningkatnya kondisi keuangan, kelebihan kapasitas/kegagalan keuangan, konsolidasi pasar internasional dan deregulasi.

Merger dan akuisisi telah menjadi praktek bisnis kontemporer dalam upaya meningkatkan kesejahteraan pemegang saham. Dari praktek bisnis ini mengundang banyak peneliti untuk melakukan penelitian. Telah banyak artikel yang dihasilkan dari hasil penelitian yang terkait dengan merger dan akuisisi. Berbagai aspek yang diteliti misalnya motivasi, dampak terhadap perusahaan yang terlibat dan karakteristiknya.

Beberapa tahun terakhir akuisisi masih menjadi strategi pertumbuhan yang paling disukai oleh perusahaan-perusahaan di Indonesia. Hal diatas berdasarkan data yang dikeluarkan oleh KPPU (Komisi Pengawas Persaingan Usaha) bahwa jumlah perusahaan yang melakukan akuisisi dari tahun 2010-2015 berjumlah 218 perusahaan. Menurut (Gitman, 2012), beberapa alasan perusahaan melakukan akuisisi ialah untuk pertumbuhan atau diversifikasi, sinergi, pengumpulan dana (fund raising), peningkatan likuiditas pemilik, dan perlindungan dari pengambilalihan. Gitman (2012) juga mengatakan akuisisi diharapkan dapat menekan atau mengurangi biaya dan meningkatkan pendapatan perusahaan dibandingkan jika perusahaan berdiri sendiri.

Selain keunggulan tersebut, akuisisi juga dapat menyebabkan menurunnya kinerja keuangan perusahaan setelah akuisisi. Banyak penelitian yang telah dilakukan mengenai kinerja perusahaan setelah akuisisi. Afrinaldi (2003) melakukan pengujian terhadap kontribusi laba anak perusahaan yang diakuisisi oleh PT Telekomunikasi Indonesia Tbk. Hasil penelitian menunjukkan bahwa kontribusi laba dari anak perusahaan setelah akuisisi menghasilkan nilai negatif. Penurunan kinerja keuangan juga dibuktikan oleh Lanuharsa (2012) melalui penelitian mengenai evaluasi akuisisi yang dilakukan PT Indika Energy Tbk. Hasil penelitian menunjukkan bahwa PT Indika mengalami penurunan performa setelah akuisisi yang dianalisis dari indikator profitabilitas.

Berdasarkan pemikiran dan latar belakang yang telah diuraikan di atas, penulis memilih judul "Evaluasi Kinerja Keuangan Sebelum dan Sesudah Akuisisi mengggunakan Rasio Profitabilitas"

\section{B. Landasan Teori}

1. Akuisisi

Kamus Besar Bahasa Indonesia (KBBI) menyatakan bahwa akuisisi adalah pengambilalihan kepemilikan perusahaan atau aset. Lebih lanjut, menurut UndangUndang Republik Indonesia Nomor 40 Tahun 2007 pengambilalihan adalah perbuatan hukum yang dilakukan oleh badan hukum atau orang perseorangan untuk mengambil alih saham Perseroan yang mengakibatkan beralihnya pengendalian atas Perseroan tersebut.

Akuisisi adalah suatu penggabungan usaha dimana salah satu perusahaan, yaitu pengakuisisi (acquirer) memperoleh kendali atas aset neto dan operasi perusahaan yang diakuisisi (acquiree), dengan memberikan aset tertentu, mengakui suatu kewajiban, atau mengeluarkan saham (PSAK 22, 2010).

2. Teori Penggabungan Usaha (Akuisisi)

Menurut Bösecke (2009), motif dilakukannya penggabungan usaha (akuisisi) yaitu.

a. Market-based view (pandangan berdasarkan pasar)

1. Kombinasi bisnis memberikan kemudahan untuk memasuki pasar baru dengan cepat dan dapat membantu mengatasi hambatan untuk memasuki pasar.

2. Kombinasi bisnis horizontal memberikan skala ekonomi dan keunggulan dari strategi biaya.

3. Kombinasi bisnis akan membuka kesempatan bagi perusahaan untuk bergabung atau bekerja sama dengan perusahaan lain dengan tujuan memperoleh keuntungkan. 
b. Resource-based view (pandangan berdasarkan sumber daya)

1. Kombinasi bisnis dapat mengatasi kelemahan perusahaan dalam hal sumber daya yang tidak dimiliki dengan cara melakukan transfer sumber daya dengan perusahaan lain.

2. Melalui kombinasi bisnis, perusahaan dapat mencoba untuk mentransfer, menggunakan sumber daya dan keahlian komplementer serta mencoba untuk bersama-sama membangun dan mengembangkan sumber daya dan menggabungkan pengetahuan.

3. Melalui kombinasi bisnis, perusahaan dapat mengakses keahlian yang ada dari perusahaan target atau mitra dan mencoba menginternalisasinya.

3. Teori Pembelajaran Kognitif

Teori pembelajaran kognitif menyatakan bahwa tujuan pembelajaran tidak terbatas hanya pada upaya mengetahui objek yang dipelajari, tetapi pembelajaran juga mempunyai tujuan memahami objek yang dipelajari melalui strategi pembelajaran yang tepat. Pembelajaran yang bertujuan memahami suatu objek ditandai dengan penyimpanan informasi dari memori jangka pendek ke dalam memori jangka panjang (Bathoska dan Koseska, 2012).

Selanjutnya, menurut Batkoska dan Koseska (2012), penyimpanan pengetahuan pada memori jangka panjang memungkinkan terjadinya integrasi antara pengetahuan dari pembelajaran saat ini dan pembelajaran sebelumnya. Batkoska dan Koseska (2012) juga menyatakan bahwa pengetahuan dari hasil pembelajaran suatu objek akan disimpan dan digunakan sebagai tambahan informasi dalam pengambilan keputusan di masa depan. Jadi, Batkoska dan Koseska (2012) menyimpulkan bahwa konsep pembelajaran merupakan usaha mengorganisir informasi untuk menurunkan kemungkinan kesalahan di masa depan berdasarkan pengalaman yang diperoleh dari pembelajaran sebelumnya.

Teori pembelajaran kognitif sangat bermanfaat untuk diterapkan dalam transaksi akuisisi. Banyak penelitian tentang akuisisi yang menunjukkan bahwa kinerja perusahaan setelah akuisisi mengalami penurunan. Hal tersebut dikarenakan penelitian-penelitian tersebut hanya menggunakan data 2 tahun setelah akuisisi. Berdasarkan teori pembelajaran, periode 2 tahun setelah akuisisi masih tergolong kedalam proses pembelajaran masingmasing perusahaan. Oleh karena itu, keberhasilan atau kegagalan transaksi akuisisi harus dievaluasi pada periode lebih dari 2 tahun setelah akuisisi.

\section{Rasio Profitabilitas}

Rasio ini dapat digunakan untuk mengukur kemampuan perusahaan menghasilkan keuntungan (profitabilitas) pada tingkat penjualan, aset, dan modal saham tertentu. Rasio profitabilitas yang akan digunakan dalam penelitian ini profit margin, ROA dan ROE.

\section{Metode Penelitian}

1. Jenis Penelitian

Penelitian ini dapat dikategorikan sebagai penelitian deskriptif dengan pendekatan studi kasus. Menurut Sekaran (2013), studi deskriptif (descriptive study) dilakukan untuk mengetahui dan menjelaskan objek penelitian dalam suatu situasi. Studi kasus umumnya digunakan untuk menyoroti suatu keputusan, mengapa keputusan tersebut diambil, bagaimana penerapannya, dan bagaimana hasil dari keputusan tersebut.

Pada penelitian ini akan mengevaluasi akuisisi yang dilakukan oleh PT Elang Mahkota Teknologi Tbk terhadap PT Indosiar Karya Media Tbk. Pada tahun 2011, PT Elang Mahkota Teknologi Tbk memperkokoh bisnis media dan konektivitas dengan mengakuisisi $84,77 \%$ saham stasiun pemancar televisi nasional PT Indosiar Karya Media Tbk. Keputusan PT Elang Mahkota Teknologi Tbk melakukan akuisisi merupakan keputusan yang cukup berani dan menarik untuk dianalisis karena beberapa hasil penelitian menunjukkan bahwa kinerja keuangan perusahaan mengalami penurunan setelah merger dan akuisisi. Penelitian ini akan difokuskan untuk mengevaluai beberapa hal antara lain:

Evaluasi kinerja perusahaan PT Elang Mahkota Teknologi Tbk pada posisi laporan keuangan periode tiga tahun sebelum akuisisi dari tahun 2009 - 2011 dan empat tahun setelah akuisisi dari tahun 2012-2015.

2. Evaluasi Kinerja Keuangan

Kinerja keuangan akan dievaluasi pada periode tiga tahun sebelum akuisisi dari tahun 2009 - 2011 dan empat tahun setelah akuisisi dari tahun 2012-2015. Hal tersebut dilakukan untuk mengetahui apakah terjadi sinergi atau tidak atas proses akuisisi yang dilakukan oleh PT Elang Mahkota Teknologi Tbk.

3. Rasio Profitabilitas

Rasio profitabilitas yang akan digunakan dalam penelitian ini profit margin, ROA dan ROE.

Profit Margin $=\frac{\text { Laba Bersih }}{\text { Penjualan }}$
Return On Asset $=\frac{\text { Laba Bersih }}{\text { Total Aset }}$
Return On Equity $=\frac{\text { Laba Bersih }}{\text { Modal Saham }}$

\section{Pembahasan}

\section{A. Analisis Rasio Profitabilitas}

Pada rasio profit margin periode sebelum akuisisi mengalami peningkatan dari 0,06 pada tahun 2009 menjadi 0,15 pada tahun 2010. Profit margin PT Elang Mahkota Teknologi Tbk terus mengalami peningkatan pada periode setelah akuisisi hingga mencapai 0,29 pada tahun 2015. Peningkatan profit margin menunjukkan bahwa perusahaan memiliki kemampuan menghasilkan laba yang tinggi.

Pada periode sebelum akuisisi nilai ROA mengalami peningkatan dari 0,04 pada tahun 2009 menjadi 0,12 pada tahun 2010. ROA meningkat karena meningkatnya 
laba bersih sehingga kemampuan pengembalian aktivanya juga menjadi semakin kuat. Akan tetapi pada periode setelah akuisisi ROA perusahaan mengalami penurunan menjadi sebesar 0,11 pada tahun 2015. Penurunan tersebut menunjukkan bahwa efisiensi dan efektivitas pengelolaan aset tidak lebih baik daripada periode sebelum akuisisi.

Pada periode sebelum akuisisi nilai ROE mengalami peningkatan dari 0,06 pada tahun 2009 menjadi 0,16 pada tahun 2010. Akan tetapi pada periode setelah akuisisi ROE perusahaan mengalami penurunan menjadi sebesar 0,12 pada tahun 2015. Peningkatan dan penurunan ROE dikarenakan mengikuti kenaikan dan penurunan laba bersih perusahaan.

\section{B. Perhitungan Profit Margin}

\begin{tabular}{|c|c|c|c|}
\hline Tahun & $\begin{array}{c}\text { Profit } \\
\text { Margin }\end{array}$ & Laba Bersih & Penjualan \\
\hline 2009 & 0,06 & 161.760 .045 & 2.828 .636 .049 \\
\hline 2010 & 0,15 & 503.672 .335 & 3.353 .538 .263 \\
\hline 2011 & 0,18 & 738.037 .568 & 4.136 .532 .904 \\
\hline 2012 & 0,22 & 1.029 .499 .905 & 4.681 .029 .525 \\
\hline 2013 & 0,24 & 1.364 .544 .542 & 5.792 .494 .662 \\
\hline 2014 & 0,25 & 1.470 .840 .691 & 5.983 .938 .709 \\
\hline 2015 & 0,29 & 1.839 .870 .357 & 6.429 .109 .329 \\
\hline
\end{tabular}

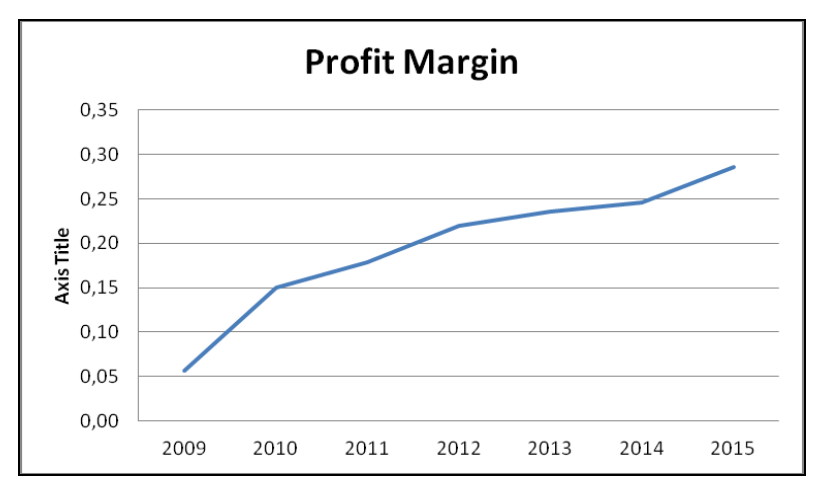

\section{Perhitungan ROA}

\begin{tabular}{|c|c|c|c|}
\hline Tahun & ROA & Laba Bersih & Total Aset \\
\hline 2009 & 0,04 & 161.760 .045 & 3.764 .885 .526 \\
\hline 2010 & 0,12 & 503.672 .335 & 4.314 .284 .667 \\
\hline 2011 & 0,10 & 738.037 .568 & 7.135 .047 .383 \\
\hline 2012 & 0,10 & 1.029 .499 .905 & 10.177 .897 .837 \\
\hline 2013 & 0,11 & 1.364 .544 .542 & 12.825 .628 .223 \\
\hline 2014 & 0,07 & 1.470 .840 .691 & 19.885 .196 .539 \\
\hline 2015 & 0,11 & 1.839 .870 .357 & 17.500 .271 .744 \\
\hline
\end{tabular}

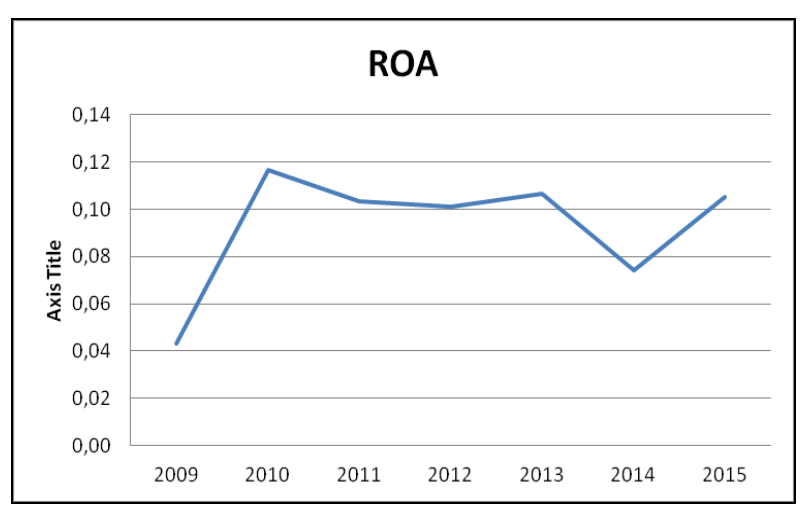

D. Perhitungan ROE

\begin{tabular}{|c|c|c|c|}
\hline Tahun & ROE & Laba Bersih & Modal Saham \\
\hline 2009 & 0,06 & 161.760 .045 & 2.615 .638 .338 \\
\hline 2010 & 0,16 & 503.672 .335 & 3.123 .548 .490 \\
\hline 2011 & 0,15 & 738.037 .568 & 4.773 .202 .907 \\
\hline 2012 & 0,13 & 1.029 .499 .905 & 7.866 .219 .392 \\
\hline 2013 & 0,15 & 1.364 .544 .542 & 9.363 .869 .390 \\
\hline 2014 & 0,09 & 1.470 .840 .691 & 16.317 .138 .942 \\
\hline 2015 & 0,12 & 1.839 .870 .357 & 15.389 .131 .186 \\
\hline
\end{tabular}

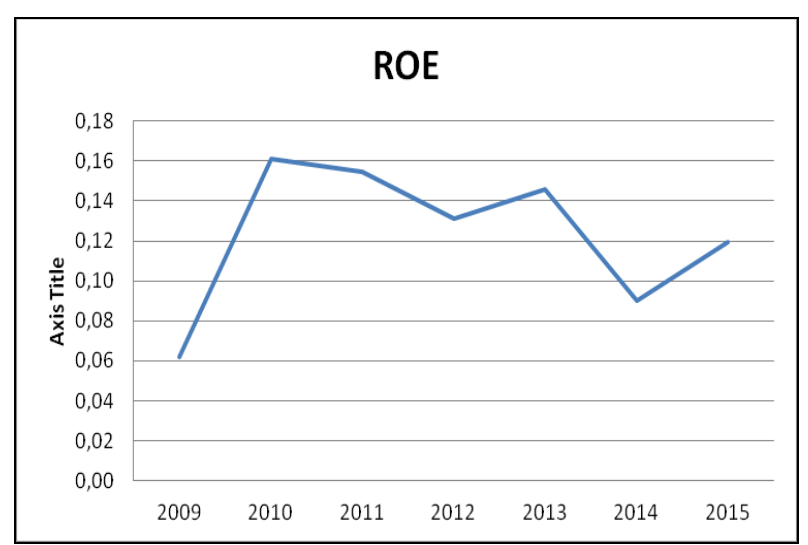

\section{Kesimpulan}

Pada rasio profit margin periode sebelum akuisisi mengalami peningkatan dari 0,06 pada tahun 2009 menjadi 0,15 pada tahun 2010. Profit margin PT Elang Mahkota Teknologi Tbk terus mengalami peningkatan pada periode setelah akuisisi hingga mencapai 0,29 pada tahun 2015. Peningkatan profit margin menunjukkan bahwa perusahaan memiliki kemampuan menghasilkan laba yang tinggi.

Pada periode sebelum akuisisi nilai ROA mengalami peningkatan dari 0,04 pada tahun 2009 menjadi 0,12 pada tahun 2010. ROA meningkat karena meningkatnya laba bersih sehingga kemampuan pengembalian aktivanya juga menjadi semakin kuat. Akan tetapi pada periode setelah akuisisi ROA perusahaan mengalami penurunan menjadi sebesar 0,11 pada tahun 2015 . Penurunan tersebut menunjukkan bahwa efisiensi dan efektivitas pengelolaan aset tidak lebih baik daripada periode sebelum akuisisi. 
Pada periode sebelum akuisisi nilai ROE mengalami peningkatan dari 0,06 pada tahun 2009 menjadi 0,16 pada tahun 2010. Akan tetapi pada periode setelah akuisisi ROE perusahaan mengalami penurunan menjadi sebesar 0,12 pada tahun 2015. Peningkatan dan penurunan ROE dikarenakan mengikuti kenaikan dan penurunan laba bersih perusahaan.

\section{Daftar Pustaka}

Afrinaldi. 2003. "Pengaruh akuisisi terhadap kinerja keuangan perusahaan Analisis Economic Value Added. (Studi kasus di PT Telekomunikasi Indonesia Tbk)." Thesis S-2. Sekolah Pascasarjana Universitas Gadjah Mada.

Batkoska, L. dan E. Koseska. 2012. The Impact of Cognitive Learning on Consumer Behaviour. Procedia: Social and Behavioral Siences. 44: 7077.

Bösecke, Kathrin. 2009. Value Creation in Mergers, Acquisitions, and Alliances. Germany: GWV Fachverlage GmbH, Wiesbaden.

Gitman, L. J., \&Zutter, C. J. 2011. Principles of Managerial Finance. Boston: Prentice Hall.

Hanafi, Mamduh M, 2016, Manajemen Keuangan, Edisi 2, Yogyakarta: BPFE.

Ikatan Akuntansi Indonesia. 2010. Exposure Draft Pernyataan Standar Akuntasi Keuangan (PSAK) no. 22 tentang Kombinasi Bisnis (revisi 2010). Dewan Standar Akuntansi Keuangan, Jakarta.

Komisi Pengawas Persaingan Usaha. Pemberitahuan Merger 2010. Diakses pada 4 Oktober 2017. http://www.kppu.go.id/id/merger-danakuisisi/publikasi-pemberitahuan/

Komisi Pengawas Persaingan Usaha. Pemberitahuan Merger 2011. Diakses pada 4 Oktober 2017. http://www.kppu.go.id/id/merger-danakuisisi/publikasi-pemberitahuan/pemberitahuanmerger-2011/

Komisi Pengawas Persaingan Usaha. Pemberitahuan Merger 2012. Diakses pada 4 Oktober 2017. http://www.kppu.go.id/id/merger-danakuisisi/publikasi-pemberitahuan/pemberitahuanmerger-2012/

Komisi Pengawas Persaingan Usaha. Pemberitahuan Merger 2013. Diakses pada 4 Oktober 2017. http://www.kppu.go.id/id/merger-danakuisisi/publikasi-pemberitahuan/pemberitahuanmerger-2013/

Komisi Pengawas Persaingan Usaha. Pemberitahuan Merger 2014. Diakses pada 4 Oktober 2017. http://www.kppu.go.id/id/merger-danakuisisi/publikasi-pemberitahuan/pemberitahuanmerger-2014/

Komisi Pengawas Persaingan Usaha. Pemberitahuan Merger 2015. Diakses pada 4 Oktober 2017. http://www.kppu.go.id/id/merger-danakuisisi/publikasi-pemberitahuan/pemberitahuanmerger-2015/
Lanuharsa, Gerhad. 2012. "Evaluasi akuisisi PT Petrosea. Tbk (PTRO) oleh PT Indika Energy. Tbk (INDY)." Thesis S-2. Sekolah Pascasarjana Universitas Gadjah Mada.

Parrino, James D., Babson College, dan Robert S. Harris. 1999. Takeovers, Management Replacement, and Post-Acquisition Operating Performance: Some Evidence From the 1980s. University of Virginia.

Saham Ok. 2010. Perusahaan Merger dan Akuisisi 2010. Diakses pada 4 Oktober 2017. https://www.sahamok.com/perusahaan-merger-danakuisisi/perusahaan-merger-dan-akuisi-2010/

Saham Ok. 2011. Perusahaan Merger dan Akuisisi 2011. Diakses pada 4 Oktober 2017. https://www.sahamok.com/perusahaan-merger-danakuisisi/perusahaan-merger-dan-akuisi-2011/

Saham Ok. 2012. Perusahaan Merger dan Akuisisi 2012. Diakses pada 4 Oktober 2017. https://www.sahamok.com/perusahaan-merger-danakuisisi/perusahaan-merger-dan-akuisi-2012/

Saham Ok. 2013. Perusahaan Merger dan Akuisisi 2013. Diakses pada 4 Oktober 2017. https://www.sahamok.com/perusahaan-merger-danakuisisi/perusahaan-merger-dan-akuisi-2013/

Saham Ok. 2014. Perusahaan Merger dan Akuisisi 2014. Diakses pada 4 Oktober 2017. https://www.sahamok.com/perusahaan-merger-danakuisisi/perusahaan-merger-dan-akuisi-2014/

Saham Ok. 2015. Perusahaan Merger dan Akuisisi 2015. Diakses pada 4 Oktober 2017. https://www.sahamok.com/perusahaan-merger-danakuisisi/perusahaan-merger-dan-akuisisi-2015/

Santi. 2016. "Dampak Akuisisi Perusahaan Terhadap Kinerja Keuangan pada PT Mahaka Media, Tbk dan Entitas Anak."

Sekaran, Uma. 2006. Research Methods for Business Buku 1 Edisi 4. Jakarta: Salemba Empat.

Sekaran, Uma, dan Roger Bougie. 2013. Research Methods for Business. John Wiley \& Sons, Ltd.

Sitio, Alfian. 2015."Analisis Kinerja Keuangan PT Media Nusantara Citra Sebelum dan Sesudah Mengakuisisi PT Cipta TPI dengan Menggunakan Metode EVA Periode 2008-2014."

Trautwein, Friedrich. 1990. Merger Motives and Merger Prescriptions. Strategic Management Journal, Vol. 11, No. 4, pp. 283-295. John Wiley \& Sons, Ltd.

United Nations Conference on Trade and Development. 2000. World Investment Report.

UU No. 40 Tahun 2007 Tentang Perseroan Terbatas.

Yin, Robert K. Case Study Research: Design and Methods, Second Edition. USA: Sage Publications 